\title{
Passalid (Insecta: Coleoptera: Passalidae) collected from trunks of Scleronema micranthum (Malvaceae)
}

\author{
Raimunda Liege Souza de ABREU ${ }^{1 *}$, Beatriz RONCHI-TELES ${ }^{2}$, Bazilio Frasco VIANEZ ${ }^{1}$, Claudio Ruy \\ Vasconcelos da FONSECA², Fernando Bernardo Pinto GOUVEIA², Ediene Borges da SILVA² \\ ${ }^{1}$ Instituto Nacional de Pesquisas da Amazônia, Coordenação de Tecnologia e Inovação, Av. André Araújo, 2936, Petrópolis, CEP 69080-971, Manaus, Amazonas, Brasil. \\ ${ }^{2}$ Instituto Nacional de Pesquisas da Amazônia, Coordenação de Biodiversidade, Av. André Araújo, 2936, Petrópolis, CEP 69080-971, Manaus, Amazonas, Brasil. \\ * Corresponding author: raiabreu@inpa.gov.br
}

\section{ABSTRACT}

Some beetles can attack the wood immediately after the tree is felled, but there are those that start their attack at different stages of wood degradation. Beetles of the family Passalidae belong to this latest category. The objective of this study was to assess the occurrence of beetles of this family in wood samples taken from trunks of Scleronema micranthum, a forest species from Central Amazon. The samples were exposed to biodegradation for 24 months on the forest ground of the Experimental Station of Tropical Silviculture of the National Institute for Amazonian Research, in Manaus, Amazon State, Brazil. During that period, 15 samples were removed from the experiment, every two months, for insect collection and evaluation of infestation. The presence of six species was recorded, all of them of the Passalini tribe: Passalus (Pertinax) latifrons, P. (Passalus) variiphyllus, P. (Pertinax) convexus, P. (Passalus) interstitialis, P. (Passalus) lanei, and Paxillus leachi. Among these species, P. (Passalus) interstitialis was the most abundant, with 18 individuals. This species was the first one to infest the samples and was found between the eighth and twentieth month of the experiment. The infestation occurred predominantly in the bark and sapwood.

KEYWORDS: Amazon wood, beetle, Passalidae, degradation.

\section{Passalídeos (Insecta: Coleoptera: Passalidae) coletados em troncos de Scleronema micranthum (Malvaceae)}

\section{RESUMO}

Alguns besouros atacam a madeira imediatamente após o abate da árvore, enquanto outros preferem a madeira em diferentes estágios de degradação. Nesta categoria estão inseridos os besouros da família Passalidae. O objetivo deste estudo foi avaliar a ocorrência de besouros dessa família em amostras provenientes de troncos de Scleronema micranthum, espécie florestal da Amazônia Central. As amostras ficaram expostas à biodegradação durante 24 meses no solo da floresta da Estação Experimental de Silvicultura Tropical do Instituto Nacional de Pesquisas da Amazônia, em Manaus, Amazonas, Brasil. Durante esse período, a cada dois meses, 15 amostras foram removidas da floresta para a coleta desses insetos e avaliaçáo da infestação. Foi registrada a presença de seis espécies, todas da tribo Passalini: Passalus (Pertinax) latifrons, P. (Passalus) variiphyllus, P. (Pertinax) convexus, P. (Passalus) interstitialis, P. (Passalus) lanei e Paxillus leachi. Dentre as espécies, P. (Passalus) interstitialis foi a mais abundante, com 18 indivíduos; foi a primeira a infestar as amostras e foi registrada entre o oitavo e o vigésimo mês do experimento. A infestação ocorreu predominantemente na casca e alburno da madeira.

PALAVRAS ChaVE: Besouros, madeira da Amazônia, Passalidae, degradação. 
Wood exposed to weathering becomes vulnerable to a variety of organisms from the felling or falling of the tree until its total deterioration (Hickin1975). Individuals of the family Passalidae (Insecta: Coleoptera: Scarabaeoidea) are known by colonizing the interior of decaying trunks (Reyes-Castillo 1970; 2000; Reyes-Castillo and Halffter 1984; Fonseca and Reyes-Castillo 2004). Within those rotting trunks, beetles of this family find favorable shelter with little variation in humidity and temperature, where enough food for their growth and development is readily available (Reyes-Castillo and Halffter 1984). This family is distributed in tropical and temperate moist forests. It has a great morphological uniformity, saproxylophagous habits, subsocial behavior and a high diversity of species (Reyes-Castillo 1970; 2000). These species have an important role as primary decomposers, and as possible bioindicators to prioritize forest areas for conservation (Schuster 1985; Schuster et al. 2000; Fonseca and Reyes-Castillo 2004).

Although most passalids present saproxylophagous behavior, some species of the genera Passalus Fabricius, 1792 (Passalinae: Passalini) and Paxillus MacLeay, 1819 (Passalini) were found attacking dry wood (Moraes and Berti-Filho 1974).

The forest species Scleronema micranthum (Ducke) Ducke, (Malvaceae), commonly known as cardeiro, is used in the wood industry in the manufacture of furniture, carpentry, joinery, partitions, light construction, plywood, decorative veneer, among others (Silva et al. 1977). Tree size ranges from medium to large, its height varies between 23 and 40 $\mathrm{m}$ and the diameter of the trunk between 25 and $70 \mathrm{~cm}$. The heartwood has a glossy light brown color; yellow sapwood; regular grain, coarse texture; indistinct smell and taste; the parenchyma is arranged in stripes or concentric lines; a small number of pores of medium to large size and some of them are blocked by tyloses or resin; two types of rays: wide and thin (Loureiro et al. 1979). It has a moderately heavy density (0.65 to $0.75 \mathrm{~g} \mathrm{~cm}^{-3}$ ) (Freitas et al. 1992; Iwakiri et al. 2012).

In spite of the fact that this species is well known by its technological characteristics and its various final uses, information on the resistance to the attack of wood-destroying organisms is still scarce. Therefore, the objective of this study was to assess the occurrence of these insects in wood samples of the forest species $S$. micranthum from Amazon State, left on the forest ground for two years.

The area used for this study is located at the Experimental Station of Tropical Silviculture of the National Institute for Amazonian Research, about $72 \mathrm{~km}$ from Manaus, Amazon State, Brazil. The samples (180 discs with $30 \mathrm{~cm}$ in thickness) were cut from the trunks of five trees. After cutting, the discs were randomly distributed on the ground of primary forest and left for a period of two years (April 2002 to April 2004). During the period of the experiment, 15 discs were randomly removed from the forest every two months, and taken to the laboratory of Wood Entomology of the Coordination of Technology and Innovation (COTI) of the National Institute for Amazonian Research (INPA). The wood samples were cut into small pieces for the collection of the insects from the wood galleries and evaluation of infestation. The identification of the insects was made by morphological comparison with the specimens of the Invertebrate Collection of INPA. After identification, the collected insects were added to INPA's collection.

The presence of six species was recorded, all from the Passalini tribe: Passalus (Passalus) interstitialis Eschscholtz, 1829, P. (Pertinax) latifrons Percheron, 1841, P. (Passalus) lanei (Pereira, 1939), Paxillus leachi MacLeay, 1819, Passalus (Passalus) variiphyllus (Kuwert, 1891) and P. (Pertinax) convexus Dalman, 1817 (Table 1). The measurements of some morphological features of the insects are shown in table 2 .

As shown in Table 1, it can be observed that, in the period of June to October 2002, April and October 2003, and from February to April 2004 there were no registrations of the presence of beetles in the samples. The same table shows that the genus Passalus was prevalent with five species and that the species $P$. (Passalus) interstitialis was the most abundant with 18 individuals. This species was first found in the eighth month of the experiment, in December 2002. P. (Pertinax) latifrons, was the second-most abundant species with 7 individuals, recorded 11 months after the beginning of the experiment. These two species remained longer in the disks, until December 2003,

Table 1. Total insect numbers of the six species of Passalidae collected from wood samples of Scleronema micranthum, in the period of June 2002 to April 2004.

\begin{tabular}{|c|c|c|c|c|c|c|c|c|c|c|c|c|}
\hline \multirow{2}{*}{ Insect species } & \multicolumn{3}{|c|}{ Year 2002} & \multicolumn{6}{|c|}{ Year 2003} & \multicolumn{2}{|c|}{ Year 2004} & \multirow{2}{*}{ Total } \\
\hline & Jun & Oct & Dec & Feb & Apr & Jun & Aug & Oct & Dec & Feb & Apr & \\
\hline Passalus (Passalus) interstitialis & 0 & 0 & 1 & 2 & 0 & 4 & 3 & 0 & 8 & 0 & 0 & 18 \\
\hline Passalus (Pertinax) latifrons & 0 & 0 & 0 & 2 & 0 & 3 & 1 & 0 & 1 & 0 & 0 & 7 \\
\hline Passalus (Passalus) lanei & 0 & 0 & 0 & 0 & 0 & 1 & 1 & 0 & 1 & 0 & 0 & 3 \\
\hline Paxillus leachi & 0 & 0 & 2 & 0 & 0 & 0 & 0 & 0 & 0 & 0 & 0 & 2 \\
\hline Passalus (Passalus) variiphyllus & 0 & 0 & 0 & 0 & 0 & 0 & 0 & 0 & 1 & 0 & 0 & 1 \\
\hline Passalus (Pertinax) convexus & 0 & 0 & 0 & 0 & 0 & 0 & 0 & 0 & 1 & 0 & 0 & 1 \\
\hline Total Geral & 0 & 0 & 3 & 4 & 0 & 8 & 5 & 0 & 12 & 0 & 0 & 32 \\
\hline
\end{tabular}


Table 2. Morphometric data of six species of Passalidae, collected from wood samples of Scleronema micranthum.

\begin{tabular}{|c|c|c|c|c|c|c|c|}
\hline \multirow{2}{*}{ Insect species } & \multicolumn{3}{|c|}{ Length (cm) } & \multicolumn{4}{|c|}{ Width (cm) } \\
\hline & Total & Pronotum & Elytra & Head & Pronotum & Elytra & Head \\
\hline Passalus (Passalus) interstitialis & 2.4 & 0.7 & 1.4 & 0.4 & 0.6 & 0.7 & 0.3 \\
\hline Passalus (Pertinax) latifrons & 2.8 & 1.1 & 1.6 & 0.5 & 0.7 & 0.9 & 0.7 \\
\hline Passalus (Passalus) lanei & 2.5 & 0.9 & 1.3 & 0.4 & 0.7 & 0.8 & 0.5 \\
\hline Passalus (Passalus) variiphyllus & 2.3 & 0.6 & 1.9 & 0.5 & 0.8 & 1.0 & 0.6 \\
\hline Passalus (Pertinax) convexus & 4.3 & 1.7 & 2.2 & 0.7 & 1.3 & 2.2 & 1.1 \\
\hline Paxillus leachi & 1.8 & 0.3 & 1.0 & 0.3 & 0.5 & 0.6 & 0.4 \\
\hline
\end{tabular}

but were not registered in the majority of the collections. Although six species were recorded, the number of individuals for each species was small, particularly for the species $P$. (Passalus) variiphyllus and P. (Pertinax) convexus, with only 1 specimen each.

During the infestation analysis of the samples, it was observed that the first attack occurred in the region in contact with the ground, spreading into other areas, as the deterioration of the wood increased. Most of these species were found in the bark and sapwood, except for P. (Pertinax) convexus, which was also located at the heartwood.

The tribe Passalini is widely distributed in the American continent, from Northern Mexico to northern Argentina and Uruguay, including the Antilles (Amat-García 2007). It has 33 genera, of which five are Americans, with a great diversity of species in the northern regions of South America (AmatGarcía et al. 2004).

The genus Passalus, prevalent in the samples of $S$. micranthum, was also frequent in the rotting trunks in the Amazon forest evaluated by Fonseca (1988), by Buhrnheim and Aguiar (1991) and by Mouzinho and Fonseca (1998). It is widely distributed in the Americas and occurs from northern Mexico to Argentina, including the Greater and the Lesser Antilles. It has 150 species in the subgenera: Pertinax Kaup, 1869, Mitrorhinus Kaup, 1871 and Passalus s. str. (Hincks and Dibb 1935). P. (Passalus) interstitialis is a Neotropical species distributed from Colombia to Argentina and Paraguay, including Trinidad. In the West Indies it occurs in Cuba and Jamaica (Boucher 1986; Reyes-Castillo and Amat-García 2003). P. (Pertinax) latifrons, is also a Neotropical species, distributed in Guyana, French Guyana, Suriname, Brazil and Peru (Reyes-Castillo 1973). P. (Passalus) variiphyllus is a Guyanese Amazonian species distributed in Brazil, Colombia, Guyana and French Guyana (Boucher 1986; Amat-García et al. 2004). P. (Pertinax) convexus is an endemic species from South America and restricted to lowland moist forests with altitudes ranging from 0 to $900 \mathrm{~m}$ (Boucher 1990). Its distribution includes Argentina, Bolivia, Chile, Brazil, Colombia, Ecuador, Guyana, French Guyana, Peru, Trinidad and Venezuela (Boucher 1990).
The genus Paxillus is also widely distributed in the Neotropics, from Mexico to the southeast of Paraguay, including the Greater Antilles, totaling nine species (ReyesCastillo and Fonseca 1992; 1997). P. leachi is a Neotropical species of wide distribution from the north of the Isthmus of Tehuantepec in Mexico to northern Argentina (Reyes-Castillo 1973; Boucher 1986; Reyes-Castillo and Fonseca 1992). In Brazil, this species has a wide distribution, occurring from the far north to the far south of the Pampas, including areas to the west of its border, as the Andean region, always found colonizing decaying logs (Fonseca et al. 2008).

Generally, the life cycle of the Passalidae lasts from two to three months and the species of this family have several reproductive cycles during the year (Castillo and Morón 1992). These cycles are related to the habitat outside the trunk, subject to constant changes, although some species show considerable differences in reproduction rate, due to exploitation of different ecological niches within the trunk (Fonseca 1988).

It was observed that all species were found in the samples in the second and third stages of deterioration when the trunks, in spite of the presence of the bark, were already excessively wet and soft. The species $P$. (Passalus) interstitialis was present for long periods in the samples, generally living under the bark and is one of the earliest settlers, preferring trunks in decaying stages as mentioned above (Rodríguez 1985; Rodríguez and Zorrilla 1986; Boucher 1986; Fonseca 1988; Castillo and Morón 1992). Buhrnheim e Aguiar (1991), evaluating rotting trunks in the Amazon rainforest, observed that this species colonizes preferentially, the bark followed by sapwood, without reaching the heartwood, which is in accordance with the observations obtained in this work. The fact that this species was found in the samples during the period of 13 months of the experiment, can be related to oviposition period and the number of eggs laid during each reproductive cycle, which can reach 542 (Morón et al.. 1988).

Another species that colonized some samples over a long period was $P$. (Perinax) latifrons. Its preference for bark and sapwood was detected in this work and is consistent with the observations made by Fonseca (1988). 
The reduced number of specimens found in the samples may be related to the exposure time in the forest, which was not enough for some species to continue the colonization.

\section{ACKNOWLEDGEMENTS}

The authors are grateful to Frank Antônio de Oliveira Campos and Jânio da Costa Santos for their valuable collaboration in setting up the experiment and collecting the insects.

\section{REFERENCES}

Amat-García, G. 2007. Los Passalidae (Coleoptera: Scarabaeoidea) del Departamento del Amazonas, Colombia. Caldasia, 29:329354.

Amat-García, G.D.; Blanco-Vargas, E.; Reyes-Castillo, P. 2004. Lista de especies de los escarabajos pasálidos (Coleoptera: Passalidae) de Colombia. Biota Colombiana, 5:173-182.

Boucher, S. 1986. Contribution a l'etude des Passalidae GuyanoAmazoniens (Coleoptera: Scarabaeoidea). Anales de la Société Entomologique de France (N.S.), 22:491-533.

Boucher, S. 1990. Note systématique, chorologique et écoaltitudinale sur quelques Pertinax Kaup: convexus Dalman (sulcifrons Kuwert, reval.), radiatus Kuwert et pseudoconvexus n. sp. (Coleoptera, Passalidae). Nouvelle Revue d'Entomologie (N.S.), 7:349-367.

Buhrnheim, P.F.; Aguiar, N.O. 1991. Passalideos (Coleoptera) da Ilha de Maracá, Roraima. Acta Amazonica, 21:25-33.

Castillo, M.L.; Morón, M.A. 1992. Observación sobre la degradación de madera por algunas especies de pasálidos (Coleoptera, Lamellicornia). Folia Entomológica Mexicana, 84:35-44.

Fonseca, C.R.V. 1988. Contribuiçấo ao conhecimento da bionomia de Passalus convexus Dalman, 1817 e Passalus latifrons Percheron, 1841 (Coleoptera: Passalidae). Acta Amazonica, 18:197-222.

Fonseca, C.R.V.; Reyes-Castillo, P. 2004. Synopsis on Passalidae family (Coleoptera: Scarabaeoidea) of Brazil with description of a new species of Veturius Kaup, 1871. Zootaxa, 789:1-26.

Fonseca, C.R.V.; Gouveia, F.B.P.; Fernandez, M.F.S. 2008. A new Paxillus MacLeay, 1819 (Coleoptera: Passalidae: Passalinae) from the state of Amazonas, Brazil. Acta Amazonica, 38:811-814.

Freitas, J.A.; Vasconcellos, F.J.; Silva, N.B.; Loureiro, A.A. 1992. Madeiras da Amazônia que apresentam raios largos. Acta Amazonica, 22:91-161.

Hickin, N.E. 1975. The Insect Factor in Wood Decay. $3^{\text {rd }}$ ed. (rev.). Associated Business Programmes Ltd, London. 383p.

Hincks, W.D.; Dibb, J.R. 1935. Passalidae, pars 142. In: Schenkling, S. (Ed.).Coleopterorum catalogus. v. XIX. W. Junk s'Gravenhage. p 1 - 118.

Iwakiri S., Vianez, B.F., Weber C., Trianoski, R., Almeida V.C. 2012. Avaliação das propriedades de painéis aglomerados produzidos com resíduos de serrarias de nove espécies de madeiras tropicais da Amazônia. Acta Amazonica, 42:59-64.

Loureiro, A.; Silva, M.F.; Alencar, J.C. 1979. Essências madeireiras da Amazônia. Vol. 1. INPA, Manaus. 245p.

Moraes, G.J.; Berti-Filho, E. 1974. Coleobrocas que ocorrem em essências florestais. Boletim IPEF, 9:27-42.
Morón, M.A.; Valenzuela, J.; Terrón, R. 1988. La macro-coleópterofauna saproxilófila del Soconusco, Chiapas, México. Folia Entomológica Mexicana, 74: 145-158.

Mouzinho, J.; Fonseca, C. 1998. Contribuição ao estudo da Passalidofauna (Coleoptera, Scarabaeoidea, Passalidae) em uma área de terra firma da Amazônia Central. Acta Zoológica Mexicana, 73: 19-44.

Reyes-Castillo, P. 1970. Coleoptera Passalidae: Morfología y división en grandes grupos: géneros americanos. Folia Entomológica Mexicana, 20-22:1-240.

Reyes-Castillo, P. 1973. Passalidae de la Guayana Francesa (Coleoptera, Lamellicornia Bulletin du Museum national d'Histoire Naturelle, 3e série, Zoologie, 197:1541-1587.

Reyes-Castillo, P. 2000. Coleoptera Passalidae de México. In: MartínPiera, F; Morrone, J.J.; Melic, A. (Ed.). Monografías Tercer Milenio, vol. 1, Sociedad Entomológica Aragonesa, Zaragoza, p. 171-182.

Reyes-Castillo, P.; Halffter, G. 1984. La estructura social de los Passalidae (Coleoptera: Lamellicornia). Folia Entomológica Mexicana, 61:49-72.

Reyes-Castillo, P.; Fonseca, C.R.V. 1992. Contribución al conocimiento de Paxillus MacLeay, con la descripción de una nueva especie amazónica (Coleoptera: Lamellicornia). Folia Entomológica Mexicana, 84:15-33.

Reyes-Castillo, P.; Fonseca, C.R.V. 1997. Paxillus MacLeay (Coleoptera: Passalidae): notas nomenclatoriales y descripción de una nueva especie. Folia Entomológica Mexicana, 101:73-78.

Reyes-Castillo, P.; Amat-García, G. 2003. Passalidae (Coleoptera) de Colombia. In: Onore, G.; Reyes-Castillo, P.; Zunino, M. (Ed.). Escarabeidos de Latinoamérica: Estado del conocimiento. Monografías Tercer Milenio, vol 3, Sociedad Entomológica Aragonesa, Zaragoza, p. 35-50.

Rodríguez, M.E. 1985. Passalus interstitialis Pascoe (Coleoptera: Passalidae) y su papel en el inicio de la descomposición de la madera en el bosque de la Estación Ecológica Sierra del Rosario, Cuba. I. Actividad en condiciones naturales. Ciencias Biológicas, 13:29-37.

Rodríguez, M.E.; Zorrilla, M.A. 1986. Passalus interstitialis Pascoe (Coleoptera: Passalidae) y su papel en el inicio de la descomposición de la madera en el bosque de la estación ecológica Sierra del Rosario, Cuba. II. Actividad en condiciones de laboratorio. Ciencias Biológicas 16:69-75.

Silva, M.F.; Lisboa, P.L.B.; Lisboa, R.C. 1977. Nomes vulgares de plantas amazônicas. INPA, Manaus. 222p.

Schuster, J.C. 1985. Pasálidos como organismos indicadores de áreas bióticas para el establecimiento de reservas biológicas. In: Godoy, J.C. (Ed.). Memorias del Primer Congreso Nacional de Biología. Guatemala 1984. Guatemala, Universidad de San Carlos de Guatemala. p. 161-169.

Schuster, J.C.; Cano, E.; Cardona, C. 2000. Un método sencillo para priorizar la conservación de los bosques nubosos de Guatemala, usando Passalidae (Coleoptera) como organismos indicadores. Acta Zoológica Mexicana (nueva serie), 80:197-209

Received: 03/06/2016

Accepted: 02/09/2016 